\title{
Evaluation of lithostratigraphic units and groundwater potential using the resolution capacities of two different electrical tomographic electrodes at dual-spacing
}

\author{
Adedibu Sunny AKINGBOYE ${ }^{1,2}$ (D) Andy Anderson BERY ${ }^{1, *}$ (D) \\ ${ }^{1}$ Geophysics Unit, School of Physics, Universiti Sains Malaysia, \\ 11800 Pulau Pinang, Malaysia \\ ${ }^{2}$ Department of Earth Sciences, Adekunle Ajasin University, \\ 001 Akungba-Akoko, Ondo State, Nigeria; \\ e-mail: adedibu.akingboye@aaua.edu.ng
}

\begin{abstract}
The selection of a choice electrode is pertinent to attenuating noise and improving geophysical tomographic inversion results. Besides, the detailed understanding of the geodynamic condition of subsurface formation is crucial to sustainable potable groundwater abstraction. Hence, the subsurface lithostratigraphic units and groundwater potential of two sites (i.e., Site 1 and Site 2) within the Universiti Sains Malaysia were evaluated using borehole-constrained electrical resistivity tomography (ERT) and induced polarisation (IP) tomography. Both methods employed the resolution capacities of stainless-steel and copper electrodes at dual-spacing. The ERT and IP field data and inversion results for copper electrodes were generally robust due to the generated higher positive data points and lower RMS errors, percentage relative differences, and mean absolute percentage errors (MAPE) than the stainless-steel electrodes, especially at Site 1 with a profile length of $200 \mathrm{~m}$ and an electrode spacing of $5 \mathrm{~m}$. However, both electrodes tend to produce inversion models with almost the same parameters at Site 2, using half the profile length and electrode spacing of Site 1, i.e., $100 \mathrm{~m}$ and $2.5 \mathrm{~m}$, respectively. Thus, the sensitivities and resolution capacities of the tomographic electrodes are heavily influenced by electrode spacing, profile length, amount of injected current, and depth of investigation. The borehole lithostratigraphic units, typically sandy silt, sand, and silty sand, have good correlations with the ERT and IP inversion results. The variability in observed resistivity and chargeability values were due to heterogeneous weathered materials and saturating water fills within the fractured and deeply-weathered granitic bedrock, with $<200 \Omega \mathrm{m}$ and a chargeability of $>1.8 \mathrm{msec}$. The models' median depth of $>40 \mathrm{~m}$ mapped for the weathered and/or fractured sections was suggestive of high groundwateryielding capacity in boreholes to sustain a part of the university community. However,
\end{abstract}

\footnotetext{
*corresponding author, e-mail: andersonbery@usm.my
} 
intended boreholes in the study area must be designed to prevent silt precipitation, which is considered a potential threat to potable groundwater and transmissivity since some sections are characterised by silt with little or no sand.

Key words: Electrical resistivity tomography (ERT), induced polarisation (IP) tomography, copper and stainless-steel electrodes, lithostratigraphy, groundwater, Penang Malaysia

\section{Introduction}

Understanding lithostratigraphic conditions, such as the nature of soil constituents, soil textures, pore spaces, thicknesses of weathered profiles, fracture density, water saturation, and fracture connectivity, among others, is necessary for the exploration of groundwater in sustainable quantities in any geologic terrain, particularly crystalline basement terrain. This is because the abundance of groundwater accumulation is localised in a Basement Complex terrain due to litho-structural dynamics of the near-surface strata and bedrock architecture (Barker and Moore, 1998; Storz et al., 2000; Soupios et al., 2007; Bery and Saad, 2012; Binley et al., 2015; Tremsin, 2017; Gao et al., 2018; Akingboye et al., 2019; Akingboye and Osasuwa, 2021; Rucker et al., 2021). Generally, groundwater is considered the safest source of freshwater existing in geologic formations and plays the most important role in man's life and socio-economic development. Groundwater is utilised for consumption, and domestic, industrial, and agricultural purposes and for keeping livestock and plants alive (Cosgrove and Loucks, 2015; Akintorinwa et al., 2020; Akingboye and Osazuwa, 2021). Groundwater is, however, vulnerable to contamination due to the occurrence of some aquifer zones at near-surface depths due to permeability, porosity, water-rock interaction, and the unconfined nature of the aquifers (Soupios et al., 200\%; Hasan et al., 2017, 2019, 2020; Akintorinwa et al., 2020; Raji and Abdulkadir, 2020).

The combined use of electrical resistivity tomography (ERT) and induced polarisation (IP) tomography has become increasingly popular in subsurface geological investigations to determine low-frequency resistive and capacitive characteristics of the subsurface geologic formations (Dahlin et al., 2002; Binley and Kemna, 2005; Cardarelli and Di Filippo, 2009; Binley, 2015; Binley et al., 2015; Amaya et al., 2016; Aladejana et al., 2020; Rucker et 
al., 2021). In recent years, ERT has been used in a variety of geophysical studies, ranging from small-scale to large-scale. The limitations arising from the ambiguity in ERT geological interpretation can be resolved using the apparent chargeability from IP survey of the investigated formation (Slater and Lesmes, 2002; Slater and Glaser, 2003; Binley and Kemna, 2005). The integration of ERT and IP can also resolve geophysical problems arising from lithology, pore fluid chemistry, degree of void spaces, and soil water content, among others (Loke, 2004; Binley and Kemna, 2005; Amaya et al., 2016; Rakoto et al., 2019; Martínez et al., 2019; Hasan et al., 2020; Akingboye and Osazuwa, 2021). Most importantly, due to the resolution capacity of electrical imaging declining rapidly with larger electrode distance, the use of borehole $\log$ can constrain the tomograms to reduce associated limitations and hence greatly improve the interpretation of complex subsurface soil profiles and bedrock architecture (Loke et al., 2013; Binley, 2015; Akingboye and Bery, 2021). On the other hand, the selection of electrodes that are capable of injecting and conducting current easily can attenuate cultural/self-potential noise and thus optimise the inversion results of ERT and IP to accurately map subsurface lateral and vertical structures (Daily et al., 2005; LaBrecque and Daily, 2008; Sirhan et al., 2011; Loke et al., 2013; Akingboye and Bery, 2021).

Besides the integration of both methods, the ERT technique has become popular in near-surface investigations due to its cost efficiency, field data acquisition speed, and robust inversion model (Loke et al., 2013; Akingboye and Ogunyele, 2019). It is used in the mapping of lithostratigraphic units, geologic boundary conditions, depth to the top of bedrock, slope monitoring, and creeping/weak soil profiles, etc (Ganerød et al., 2006; Robineau et al., 2007; Crook et al., 2008; Chalikakis et al., 2011; Bery and Saad, 2012; Bery, 2016; Amaya et al., 2018; Gourdol et al., 2018; Bery et al., 2019; Cheng et al., 2019; Akingboye et al., 2020). ERT has been widely used in groundwater/hydrogeology and environmental surveys (Daily et al., 1991; Ahmed and Sulaiman, 2001; Arora and Ahmed, 2011; Maiti et al., 2012; Muchingami et al., 2012; Arora et al., 2016; Uhlemann et al., 2017; Amaya et al., 2018; Sağır et al., 2020). The method has been used to investigate and identify hidden underground structures, control groundwater flow at larger spatial and temporal scales, and monitor river water discharge patterns (Storz et al., 2000; Hayley et al., 2009; Coscia et al., 2012; Karim and 
Tucker-Kulesza, 2017, 2018; Hojat et al., 2020; McLachlan et al., 2020).

The study area is located within the main campus of the Universiti Sains Malaysia (USM), Penang Island, Malaysia. Peninsular Malaysia is a tropical country that experiences both high atmospheric temperatures and torrential rainfall almost all year. These processes enhance the progressing weathering of the feldspar-rich granites in the area (Ong, 1993; Ahmad et al., 2006) to form varying weathered strata and subsurface soil-rock structures that are good conduits for groundwater. However, the clayey/silty nature of subsurface weathered strata (Bery, 2016; Akingboye and Bery, 2021) could pose a serious challenge to sustainable potable groundwater development for the growing university community. Hence, we employed the resolution capacities of two different electrodes (i.e., conventional stainless-steel and copper) at dual-spacing for the ERT and IP tomographic surveys in the study area. The study, therefore, is aimed at (1) evaluating the performance of the two electrode types through their subsurface resolution capacities based on fielddata qualities and inversion models (i.e., data points, RMS errors, and percentage relative differences); (2) characterising the lithostratigraphic units and structures that are viable for groundwater exploration; and (3) delineating and proposing potential zones that are free of clayey/silty intrusion for sufficient groundwater development. As a result, this study is intended to be a useful repository on the sensitivities and resolution capacities of tomographic electrodes in lithostratigraphic and groundwater mapping in terrain with clayey-silty soil variability and complex geology.

\section{Geological setting of the study area}

The study area is located in Minden within the Universiti Sains Malaysia (USM), Penang Island, Malaysia. The two investigated sites, i.e., Site 1 and Site 2, were located between latitudes $5^{\circ} 21^{\prime} 43.56^{\prime \prime}-5^{\circ} 21^{\prime} 44.89^{\prime \prime} \mathrm{N}$ and longitudes $100^{\circ} 18^{\prime} 20.09^{\prime \prime}-100^{\circ} 18^{\prime} 26.64^{\prime \prime} \mathrm{E}$, and $5^{\circ} 21^{\prime} 32.58^{\prime \prime}-5^{\circ} 21^{\prime} 29.15^{\prime \prime} \mathrm{N}$ and $100^{\circ} 18^{\prime} 31.32^{\prime \prime}-100^{\circ} 18^{\prime} 30.86^{\prime \prime} \mathrm{E}$, respectively, as shown in Figs. 1a and $1 \mathrm{~b}$. Peninsular Malaysia is located at the southeastern margin of the Eurasian continent and was formed by the amalgamation of the Sibumasu Block and Indo-China Block along the Bentong-Raub suture during the Permian-Triassic (Metcalfe, 2000, 2001; Ng et al., 2015a, 2015b; Cao et al., 2020). The collisional event resulted in the closure of the Paleo-Tethys ocean 


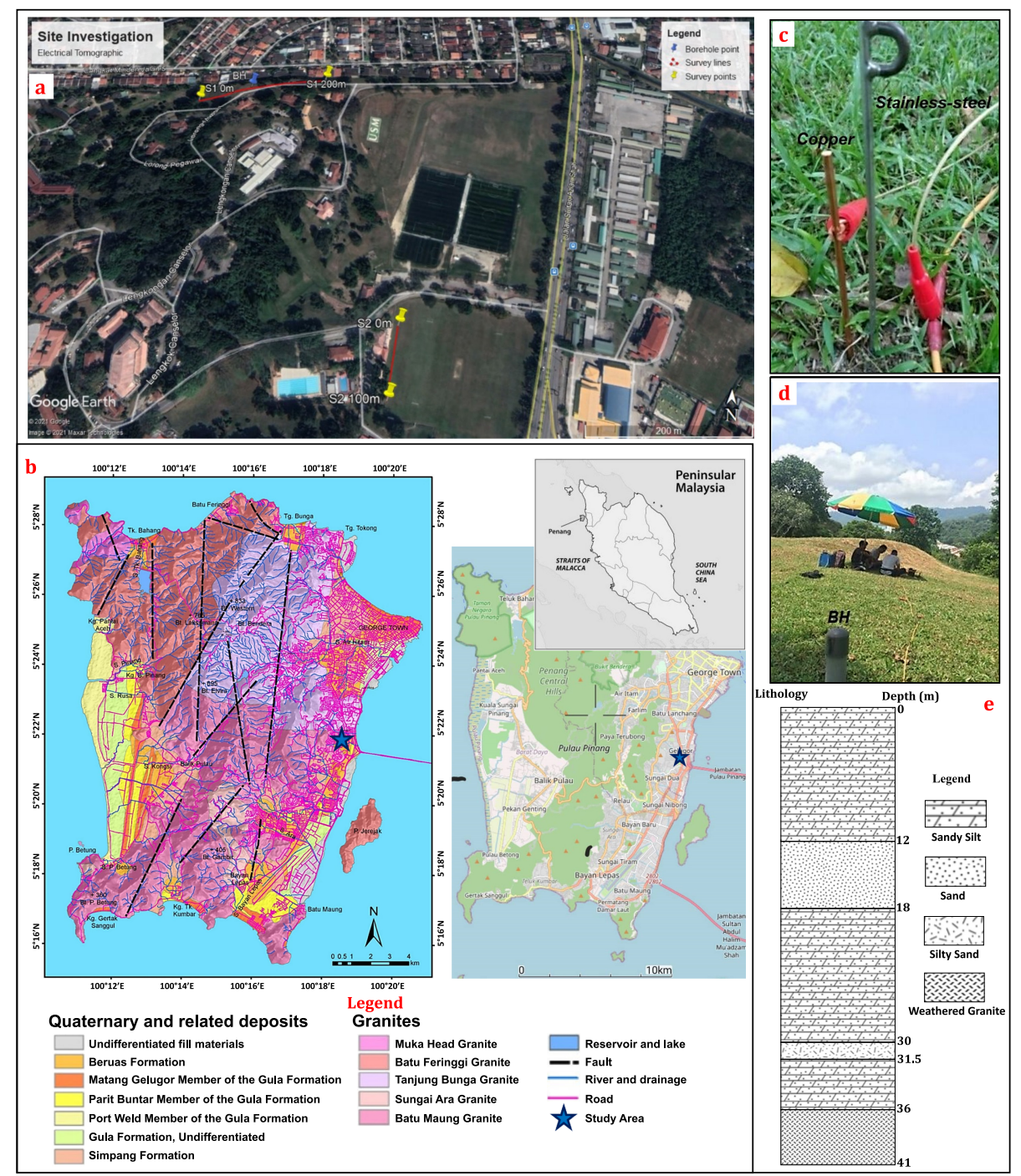

Fig. 1. (a) Aerial geophysical data acquisition map of the study area showing the two established geophysical traverses (i.e., S1 for Site 1 and S2 for Site 2) and the borehole point. (b) Geological map of Penang Island, Malaysia showing the study area (modified after Ahmad et al., 2006; Abdul Hamid et al., 2019). (c) Illustration of the study area, showing the grounded stainless-steel electrode with a curved edge and the copper electrode clipped with a jumper cable, and (d) the drilled borehole point (indicated as "BH") at Site 1. (e) Borehole log displaying the lithostratigraphic units beneath Site 1 at an 85meter station distance. 
basin, leaving the basin's remnants preserved in the Bentong-Raub Suture (Metcalfe, 2000, 2013). The Bentong-Raub and Lebir faults divide Peninsular Malaysia into Western, Central, and Eastern Belts. The CarboniferousPermian basement in the Central Belt is characterised by a sequence of limestone, shale, and subordinate sandstone, siltstone, and conglomerate (Schwartz et al., 1995). The Malaysian granitoids are typically Permianlate Triassic I-type granites located within Eastern Belt in the Indo-China domain and the late Triassic S-type granites are found within the Western and Central Belts in the Sibumasu domain, consisting of biotite granites and granodiorites ( $\mathrm{Ng}$ et al., 2015b). The S-type granites and the I-type granites of the Sibumasu blocks and Indo-China blocks, respectively, were formed through the partial melting of the metamorphic basement during the collision ( $\mathrm{Ng}$, 2015a, 2015b; Cao et al., 2020). The granitoids are known as the Main Range Granite Province and the Eastern Granite Province and are surrounded by the Bentong-Raub Suture. The approximately NS trending faults are widespread in the region due to the collision event (Abdullah and Purwanto, 2001).

Penang Island is located on the northern side of Peninsular Malaysia. The island is underlain by igneous rock, typically granite (Fig. 1b). The granites of Penang Island are divided into the North Penang Pluton and the South Penang Pluton based on the proportion of alkali feldspar to total feldspar. The North Penang Pluton granites are rich in orthoclase and intermediate microcline, while their South Penang Pluton counterparts contain microcline (Ong, 1993; Ahmad et al., 2006). The North Penang Pluton is divided into three groups: the Tanjung Bungah group, Paya Terubong group, and the Batu Ferringhi group. The Tanjung Bungah group is located north of Penang and is made up of medium-to-coarse-grained biotite granites that were formed in the early Jurassic. These granites are predominantly rich in orthoclase and intermediate microcline feldspar. The Paya Terubong group is situated southeast of Penang Island with an age of early Permian to late Carboniferous and is composed of medium-to-coarsegrained biotite granite with microcline. The Batu Ferringhi group, located on the northwestern coast of Penang Island, is characterised by medium-tocoarse-grained biotite granite of the early Jurassic age. The granites consist of predominantly orthoclase and intermediate microcline feldspar. 


\section{Methodology}

The two investigated sites, i.e., Site 1 and Site 2, were located in the same vicinity but separated by few building blocks within USM. The survey line employed at Site 1 was $200 \mathrm{~m}$ in length with an electrode spacing of $5 \mathrm{~m}$, whereas a spread length of $100 \mathrm{~m}$ with an electrode spacing of $2.5 \mathrm{~m}$ was used at Site 2. Both sites used the same numbers of electrodes, comprising a total of 41 electrodes each, for two different electrode types (i.e., stainlesssteel and copper electrodes), as shown in Fig. 1c. The variation in profile length and electrode spacing was aimed at determining the efficiency of each of the used electrode types and for detailed evaluation of both small and large electrode spacing in the tomographic surveys. The ABEM LUND Imaging System, consisting of the ABEM SAS Terrameter 4000, an electrode selector (i.e., ES 10-64C), and multi-core cable reels, was used, and the Wenner-Schlumberger array was employed for both ERT and IP field data measurements. The output current was set at $200 \mathrm{~mA}$ and the acquisition delay and time were respectively set at $0.4 \mathrm{sec}$ and $0.6 \mathrm{sec}$, while the current-off was set at $1 \mathrm{sec}$. These settings would enable the equipment to take both ERT and IP measurements during the survey. Furthermore, the positive data points were programmed to be recorded only, whilst all the negative data points were rejected automatically. The method improved the resolution of field data; otherwise, artefacts from buried structures and/or earth material(s) could be introduced into tomograms. To have a detailed interpretation of subsurface layers with depths, an existing borehole (BH) $\log$ at the station distance of $85 \mathrm{~m}$ at Site 1, as shown in Figs. 1d and 1e, was used to constrain the generated ERT and IP inversion results and to determine the nature of the lithostratigraphic units in the study area. The borehole has a total depth of about $41 \mathrm{~m}$. The drilled borehole, however, did not reach the fresh bedrock, hence, the depth to the top of the fresh bedrock was not recorded.

The ERT and IP acquired field data sets were processed and iteratively inverted using RES2DINV software. The inversion methods involving the use of forward modelling and data inversion to determine the true resistivity/chargeability distribution of the subsurface formation are well documented in the works of deGroot-Hedlin and Constable (1990), Silvester and Ferrari (1996), Loke (2004), Binley and Kemna (2005), Dahlin and Loke (2018), and Akingboye and Ogunyele (2019), among others. The fi- 
nite-element method of 4 nodes with $\mathrm{L}_{2}$-norm was used as the least-squares constraint to obtain the best tomographic inversion models by minimise the differences between the calculated and observed apparent resistivity and chargeability values. Also, a damping factor of 0.05 with a minimum value of 0.01 was employed to stabilise the inversion process and increase the accuracy of the calculated apparent resistivity and chargeability values and the resolution of the generated final inversion models. We adopted RMS error analysis to achieve a cut-off error point of $30 \%$ from a maximum error of $200 \%$ to generate the inverse model sections with apparent resistivity and chargeability percentage errors of below $30 \%$, and impotantly, to avoid the extermination of valuable data points. The iterations of ERT and IP inversions were limited to the 7th iteration due to the RMS errors generated at the 5th iteration being relatively large. We carefully examined the inversion results from the 3rd iteration to observe changes in the subsurface structures. This is because an inverted tomographic model with the lowest convergence error limit may sometimes not give the required ideal subsurface geological structures and anomalies as suggested by Loke (2004). After several attempts, we considered the 7 th iteration as the ideal result as it yielded significantly no or small changes in error values and, at the same time, produced the most realistic subsurface inverted ERT and IP models.

Furthermore, we adopted the procedures and equations in our previous work (Akingboye and Bery, 2021) to evaluate the resolution capacities of the used electrodes for the study. The percentage relative differences between the ERT and IP inversion results were evaluated using Eq. (1), taking the data sets of the copper electrodes as the reference because their overall inversion results were proven to be reliable based on quality of data points and low RMS errors. Most importantly, Eqs. (1)-(5) were used for the analyses of additional statistical parameters, namely the mean $(\mu)$, standard deviation (SD), RMS error, and mean absolute percentage error (MAPE) to accurately evaluate the resolution capacities of both electrodes:

$X_{\% \text { relative difference }}=\frac{X_{\text {copper }}-X_{\text {stainless }- \text { steel }}}{X_{\text {copper }}} \times 100 \%$,

$\mu=\frac{1}{N} \sum_{i=1}^{N} X_{\%}$ relative difference (i), 
$\mathrm{SD}=\sqrt{\frac{\sum_{i=1}^{N}\left(X_{\% \text { relative difference }(i)}-\mu\right)^{2}}{N}}$,

$\mathrm{RMS}=\sqrt{\frac{\sum_{i=1}^{N}\left(X_{\% \text { relative difference (i) }))^{2}}\right.}{N}}$,

$\operatorname{MAPE}=\frac{100 \%}{N} \sum_{i=1}^{N} \mid X_{\%}$ relative difference $(i) \mid$.

where $X$ represents the measured geophysical parameters, i.e., resistivity and chargeability in $\Omega \mathrm{m}$ and msec, respectively.

\section{Results and Discussion}

\subsection{Resolution capacities of electrical tomographic (ERT and IP) electrodes in subsurface investigations}

The ERT and IP results of the acquired total positive data points before and after filtering for both electrodes at the two sites are presented in Fig. 2. For Site 1, the stainless-steel and copper electrodes recorded a total of 386 and 413 positive data points, respectively, before filtering. At Site 2, the copper electrodes obtained 415 positive data points compared to the stainless-steel

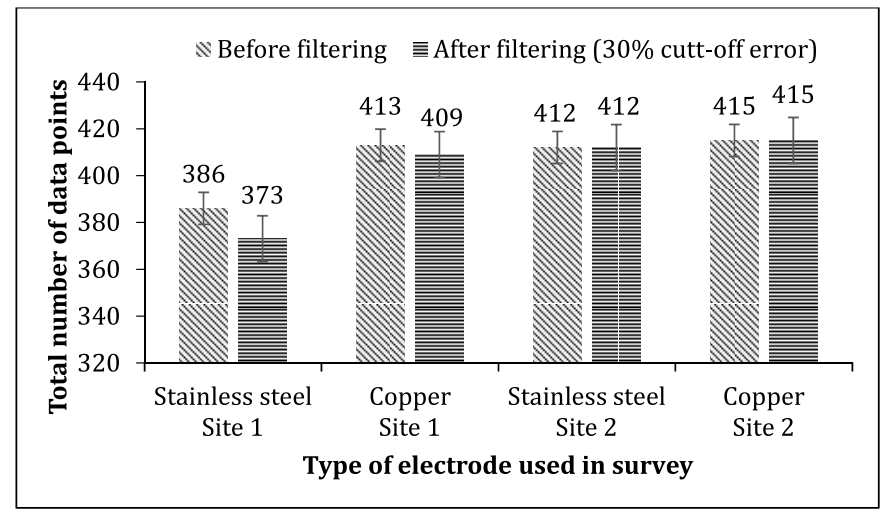

Fig. 2. A comparative bar plot of the total number of positive data points before filtering and after filtering from the two investigated sites. 
electrodes with 412 positive data points. The acquired number of positive data points was reduced by 13 and 4 to obtain 373 and 409 data points for the stainless-steel and copper electrodes, respectively, after filtering due to the removal of associated errors arising from cultural/self-potential noise and/or current relays. The number of data points at Site 2, however, remained unchanged after filtering for both electrode types. The capacity for high current conductivity and sensitivity of copper electrodes at increased electrode spacing resulted in a negligible drop in data points, allowing for the derivation of more subsurface information of higher quality (Daily et al., 2005; LaBrecque and Daily, 2008; Sirhan et al., 2011).

The qualities of the resistivity and chargeability values measured in the field were further analysed based on calculation from the RMS errors. The estimated RMS errors for both ERT and IP results (i.e., using stainless-steel and copper electrodes) at the two investigated sites were plotted against their iteration levels as shown in Fig. 3. The data sets from the copper electrodes at Site 1 were of good quality. The ERT inversion results

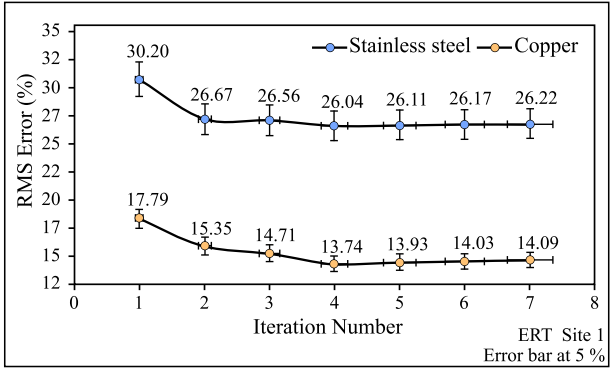

(a)

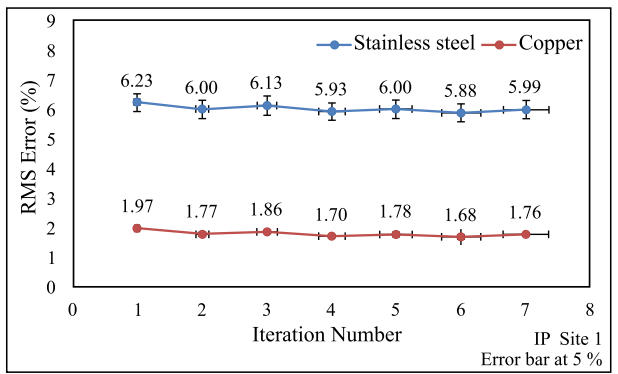

(b)

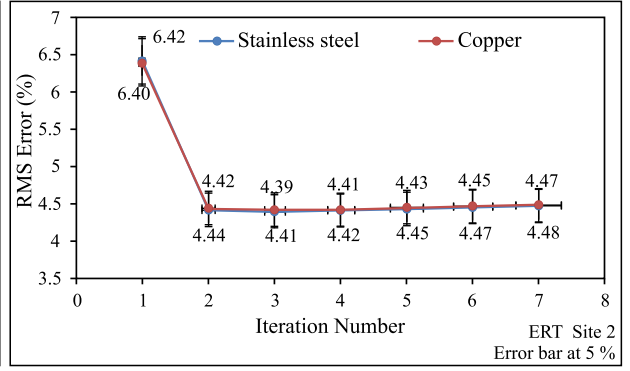

(c)

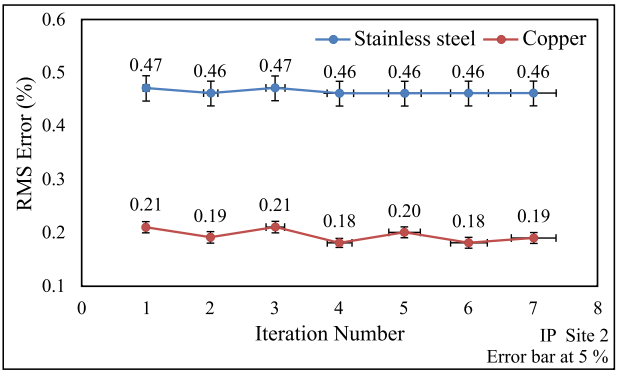

(d)

Fig. 3. Charts of \%RMS errors of inversion models derived from the 1st to 7 th iterations for $\operatorname{ERT~}(\mathrm{a}, \mathrm{b})$ and IP $(\mathrm{c}, \mathrm{d})$ for Site 1 and Site 2 data sets inversion. 
for stainless-steel electrodes yielded RMS errors decreasing from $30.2 \%$ to $26.22 \%$, whereas that of copper electrodes decreased from $17.79 \%$ to $14.09 \%$, as shown in Fig. 3a. The RMS errors of the IP inversion models ranged from $6.23 \%$ to $5.88 \%$ and $1.97 \%$ to $1.68 \%$ for the stainless-steel and copper electrodes (Fig. 3b), with exact RMS errors of approximately $6.0 \%$ and $1.8 \%$, respectively. Field measurements were stable for both electrodes at Site 2 . The ERT RMS errors reduced from $6.42 \%$ to $4.39 \%$ for the stainless-steel electrodes and $6.40 \%$ to $4.4 \%$ for the copper electrodes as shown in Fig. 3c. The IP models, on the other hand, ranged between about $0.47 \%$ and $0.46 \%$, and $0.21 \%$ and $0.18 \%$ for the stainless-steel and copper electrodes, respectively (Fig. 3d).

It is a standard practice to increase the distance between the potential electrodes when potential measurements are made for larger electrode positions between the current electrodes. This somewhat results in measurements with high RMS errors (Martínez et al., 2019). Hence, Site 1, with larger electrode spacing (i.e., $5 \mathrm{~m}$ ) and a profile length of $200 \mathrm{~m}$, significantly reduced the resolution power of the stainless-steel electrodes and the array than the recorded data sets for the copper electrodes. However, the observed results for Site 2 proved that both electrodes' performance was good for small electrode spacing (i.e., $2.5 \mathrm{~m}$ ) and profile length of $100 \mathrm{~m}$. The observation may be due to the shallower depth of penetration and/or shorter period for the injected current waveform to penetrate the subsurface formation from a short profile (Daily et al., 2005; Binley and Kemna, 2005; Martinez et al., 2019). The employed statistical analyses provided detailed insights into the performances of both electrode types and also showed that copper electrodes have higher resolution strengths and stabilities (i.e., with very low sensitivity to noise) in subsurface tomographic imaging than stainless-steel electrodes. The results from the analyses agree with other works conducted by researchers like Clark et al. (1970), LaBrecque and Daily (2008), Cardarelli and Di Filippo (2009), Sirhan et al. (2011), and Martínez et al. (2019), among others.

\subsection{Soil-rock resistivity and chargeability: characterisation of subsurface lithostratigraphic units and architecture}

The ERT and IP inversion results were analysed and correlated with the borehole log (see Fig. 1e) to delineate the subsurface lithostratigraphic units 
and their geometries and depths, as well as the potential zones with high groundwater-yielding capacity in the study area. The borehole log provided a detailed understanding of the nature of the subsurface formation rather than relying solely on ERT and IP models. We also used the resolution capacities of both electrodes as determined in Figs. 2 and 3. The resistivity and chargeability models for the stainless-steel and copper electrodes obtained beneath Site 1 are shown in Figs. 4 and 5, respectively. The 2D composite images of pseudosections of the measured, calculated, and inverted apparent resistivity and chargeability for both investigated sites are shown in Appendices 1 and 2. As shown in Fig. 4, the boreholederived subsurface lithostratigraphic units, namely the sandy silt (topsoil), sandy, and silty sand soils, have resistivity values of about $70-600 \Omega \mathrm{m}$, $400->1300 \Omega \mathrm{m}$ and $300-600 \Omega \mathrm{m}$, respectively. Using the range of chargeability values incorporated with the borehole information, we differentiated water-saturated fills from silty soils, including clean sandy. The identified lithostratigraphic units (i.e., sandy silt, sandy, and the silty sand soils) also have chargeability values ranging from about $3-6 \mathrm{msec}, 4->18 \mathrm{msec}$, and 1-4 msec, respectively, as shown in Fig. 5. The fresh granitic bedrock underlying the overburden at this site was not imaged, even at a depth extent of about $41 \mathrm{~m}$.

The characterised subsurface lithostratigraphic units beneath Site 1 was annotated as A, B, and C, corresponding to dry sand, sandy silt, and silty sand strata, respectively, as shown in Fig. 4. In Fig. 4a, the delineated dry sand (i.e., A) is at the near-surface between stations $17 \mathrm{~m}$ and $58 \mathrm{~m}$ and extends to a depth of $14 \mathrm{~m}$. Stations at a distance of $75 \mathrm{~m}$ and $110 \mathrm{~m}$ show that the dry sand occurs at a depths of $5 \mathrm{~m}$ to about $17 \mathrm{~m}$. However, this feature plunged extensively leftward in Fig. 4b. From a station distance of $120 \mathrm{~m}$ (i.e., in the topsoil) in Fig. 4a, the dry sand plunges to a depth of about $12 \mathrm{~m}$ (i.e., station $160 \mathrm{~m}$ ). Similar characteristic signatures indicating strata A was observed in Fig. 4b, but with a slight vertical dip at station $120 \mathrm{~m}$. The feature separates the two low-resistive bodies, identified as lithology B, with an oval shape, and D. This segmented section must have been a pathway (i.e., fracture) for migrating water and this may have contributed to the deeply weathered granitic bedrock (i.e., D). The sections annotated B (i.e., sandy silt) differ significantly in geometries and dipping directions as shown in Fig. 4, particularly for the oval-shaped structure adjoining strata D (see 

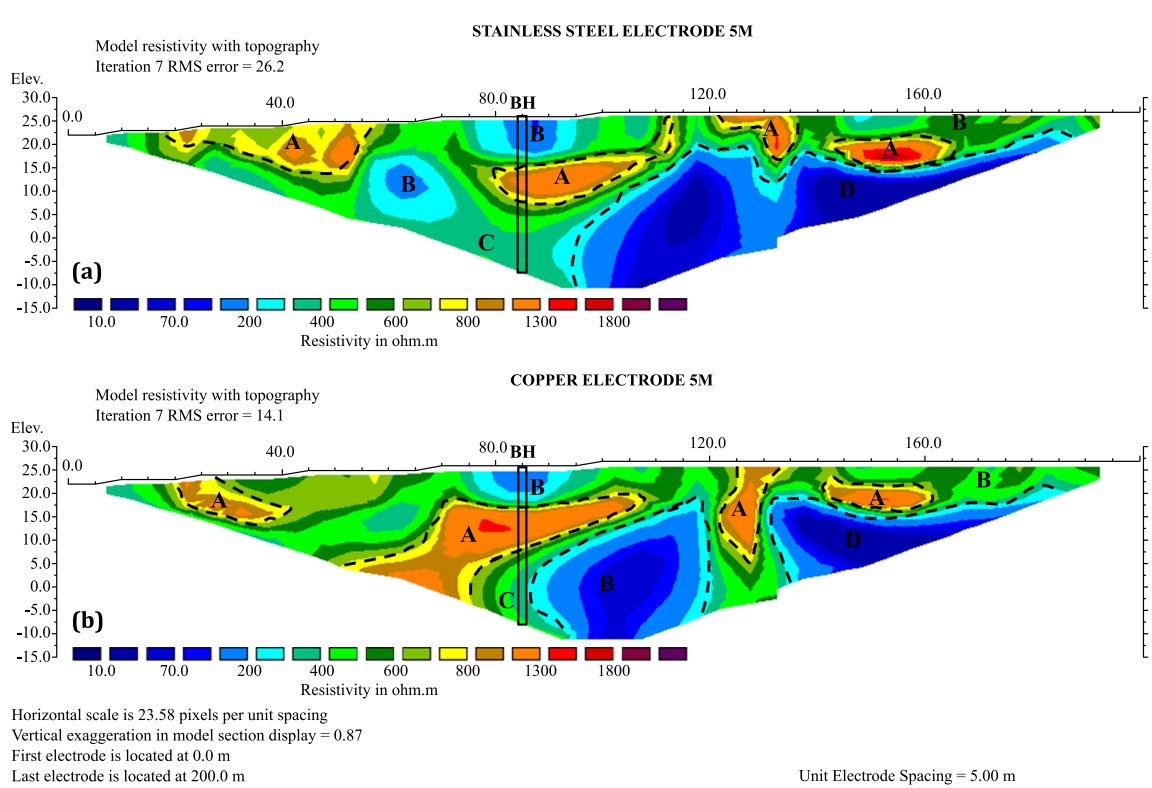

Fig. 4. ERT inversion models beneath Site 1 generated using stainless-steel electrodes (a) and copper electrodes (b) with an electrode spacing of $5 \mathrm{~m}$.

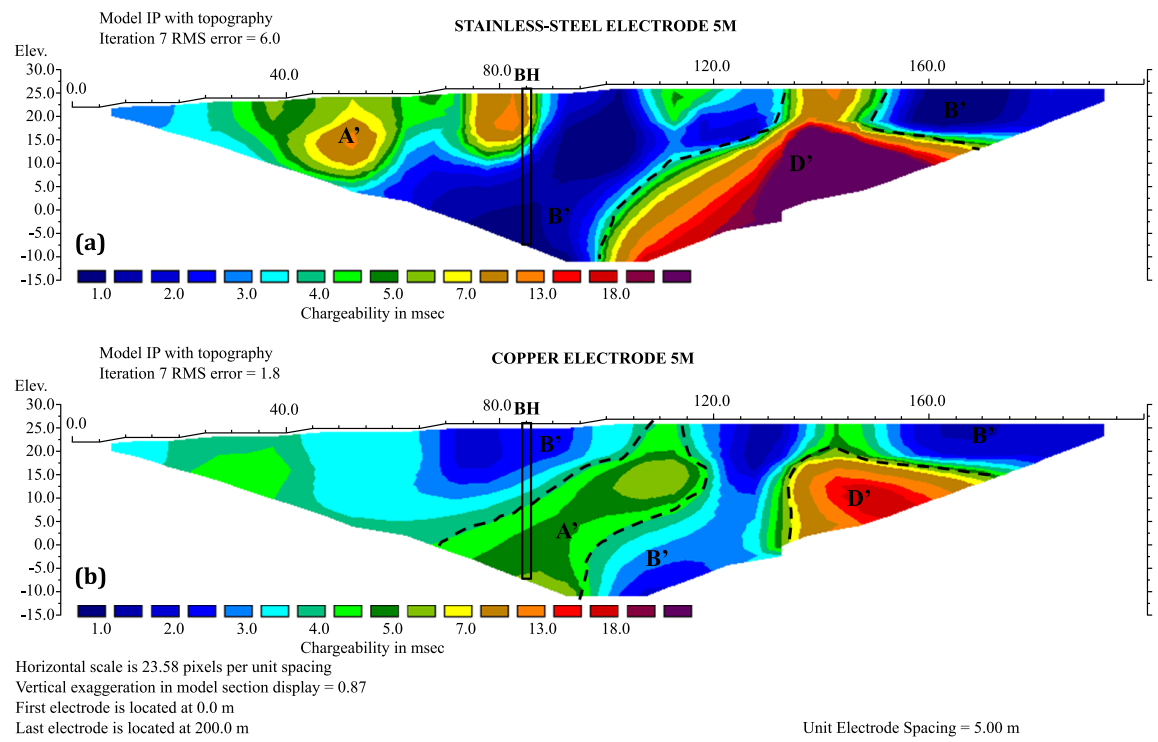

Fig. 5. IP inversion models beneath Site 1 generated using the stainless-steel electrodes (a) and copper electrodes (b) with an electrode spacing of $5 \mathrm{~m}$. 
Fig. 4b). The sections labelled C (i.e., silty sandy) occur at the depths of about $30-31.5 \mathrm{~m}$. The thin-layered soil profile may be a part of the sandy soil but must have mixed with the weathered soil produced from the deeply weathered granitic bedrock.

The IP model shown in Fig. 5, on the other hand, clearly shows that the sections $\mathrm{A}^{\prime}$ typically sand, have high chargeability values due probably to the absence of silt and high dryness. However in Fig. 5b, the sandy body (i.e., $\mathrm{A}^{\prime}$ ) dipping from the top layer to the left side of the model at an angle of about $60^{\circ}$ was fairly saturated. In Fig. 5a (i.e., the chargeability model for stainless-steel electrodes), it is shown that the section has a very low chargeability value of $<3 \mathrm{msec}$, probably due to retained water and/or silt. Both results show that the sandy silt (i.e., $\mathrm{B}^{\prime}$ ) is the major soil profile characterising the subsurface lithologies. The parts annotated $\mathrm{D}^{\prime}$ on both IP models with high chargeability values (i.e., > 13 msec) affirm that the weathered granitic bedrock produced quality sand with very low silt.

Figures 6 and 7, i.e., the ERT and IP inversion results beneath Site 2, respectively, show that the resistivity values of the sandy silt, sand, and silty sand range from about $90-600 \Omega \mathrm{m}, 400->800 \Omega \mathrm{m}$, and $200-600 \Omega \mathrm{m}$, and chargeability values of about $1.4-1.8 \mathrm{msec}, 1.8->2.4 \mathrm{msec}$, and $1.4-$ $2.2 \mathrm{msec}$, respectively. The depths of the models terminated at about $20 \mathrm{~m}$; hence, they are unable to image the deeply weathered bedrock shown in Figs. 4 and 5. The subsurface characteristic features shown in Fig. 6 are completely the same, except for a slight change observed in the central part of Fig. 7. The similarity in derived subsurface characteristic features may be due to the equally generated low RMS errors and high-resolution capacities for both electrodes as earlier discussed. The central low-resistive body (i.e., A), with resistivity and chargeability values of $<200 \Omega \mathrm{m}$ and $>2 \mathrm{msec}$ (reaching a high value of about $2.8 \mathrm{msec}$ ), is saturated in nature and was denoted as $\mathrm{A}^{\prime}$ in Fig. 7. Generally, the subsurface materials along this profile contain largely an equal proportion of sandy silt (i.e., B) and sand (i.e., A). The inclined zone $\mathrm{B}^{\prime}$, with a moderately high chargeability value of about $1.8 \mathrm{msec}$, as shown in Fig. 7a, divides the high chargeability anomaly with a slightly higher value in Fig. $7 \mathrm{~b}$. The delineated zone may be a pathway (i.e., fracture and/or deep-weathered trough) for water. The sandy soil profiles beneath Site 2 have higher retained water saturation fills than those observed in Site 1. 

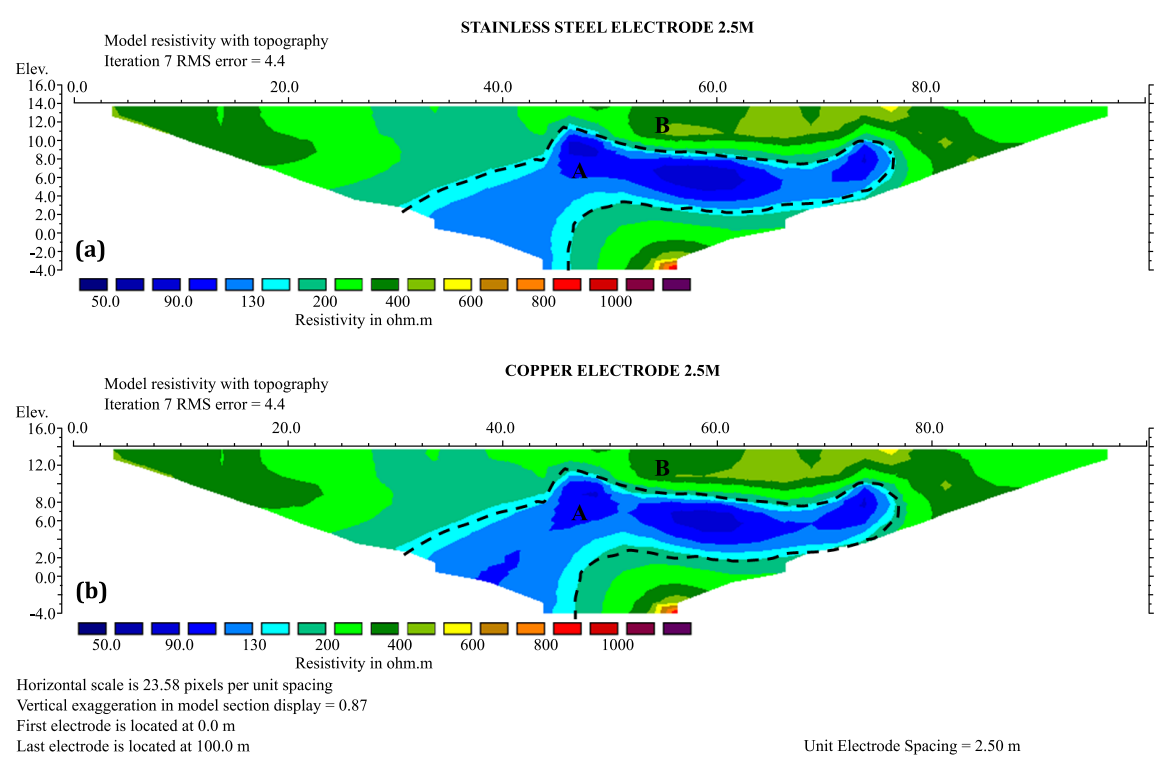

Fig. 6. ERT inversion models beneath Site 2 generated using the stainless-steel electrodes (a) and copper electrodes (b) with an electrode spacing of $2.5 \mathrm{~m}$.

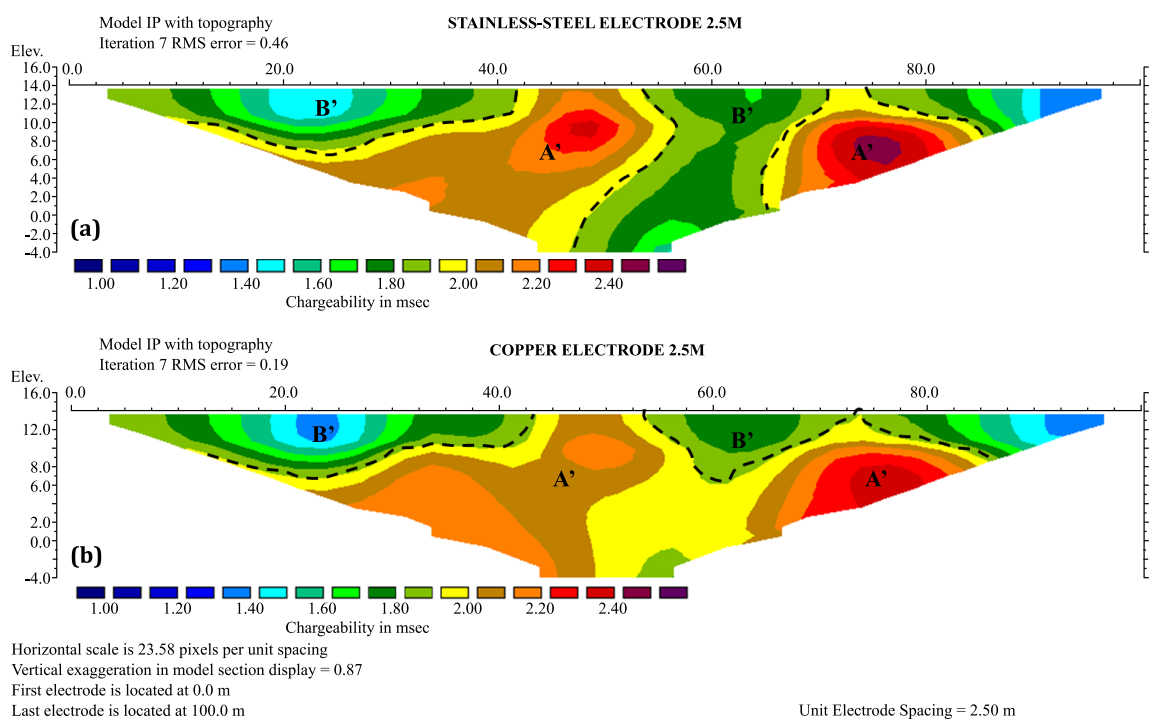

Fig. 7. IP inversion models beneath Site 2 generated using the stainless-steel electrodes (a) and copper electrodes (b) with an electrode spacing of $2.5 \mathrm{~m}$. 
The percentage relative differences between stainless-steel and copper electrodes ERT and IP inversion models shown in Figs. 8 and 9 were produced according to the declared variables in Eq. (1), using the models of copper electrodes as reference for both ERT and IP inversion results derived for Sites 1 and 2. Both figures produced well-defined and correlated $\%$ relative difference models for the identified lithostratigraphic units in the study area. The sections characterised by sand have low $\%$ relative differences with values of about $-50 \%$ to $-10 \%$ (see Fig. 8 ) and $-6 \%$ to $-2 \%$ (see Fig. 9). Sandy silt and silty sand have high $\%$ relative differences, with values of $>10 \%$ and $>1 \%$, as shown in Figs. 8 and 9, respectively. The watersaturated zones and fractured and/or deep-weathered zones have the lowest $\%$ relative differences as observed in both figures. A comprehensive summary of other estimated parameters from the percentage relative differences between the two sites is shown in Table 1. The statistical results derived for the ERT and IP models from stainless-steel electrodes are higher than those of copper electrodes. However, models of Site 2 yield considerably low values. The results, just like the statistical analyses shown in Figs. 2 and 3, have also proven that copper electrodes are capable of generating high-resolution subsurface lithostratigraphic inversion models (LaBrecque and Daily, 2008; Cardarelli and Di Filippo, 2009; Sirhan et al., 2011; Martínez et al., 2019).

Table 1. Summary of the derived statistical parameters for the ERT and IP inversion models for both investigated sites.

\begin{tabular}{lcccc}
\hline \multirow{2}{*}{ Estimated parameters (all measured in \%) } & \multicolumn{2}{c}{ Site 1 } & \multicolumn{2}{c}{ Site 2 } \\
\cline { 2 - 5 } & ERT & IP & ERT & IP \\
\hline \% Relative difference & \multicolumn{2}{c}{ \pm 70} & \multicolumn{2}{c}{ \pm 8} \\
\hline Mean $(\mu)$ & 14.457 & 12.670 & 0.328 & 0.478 \\
\hline Standard deviation (SD) & 31.909 & 44.738 & 2.799 & 3.670 \\
\hline RMS error (RMSE) & 35.031 & 46.497 & 2.819 & 3.701 \\
\hline Mean absolute percentage error (MAPE) & 28.693 & 40.253 & 2.191 & 3.055 \\
\hline
\end{tabular}

\subsection{Soil-rock resistivity and chargeability: implications on sus- tainable potable groundwater development}

The ERT and IP inversion models for the investigated sites show variability in observed resistivity and chargeability values for the delineated subsurface lithostratigraphic units, typically sandy silt, sandy, and silty sand soils, and 


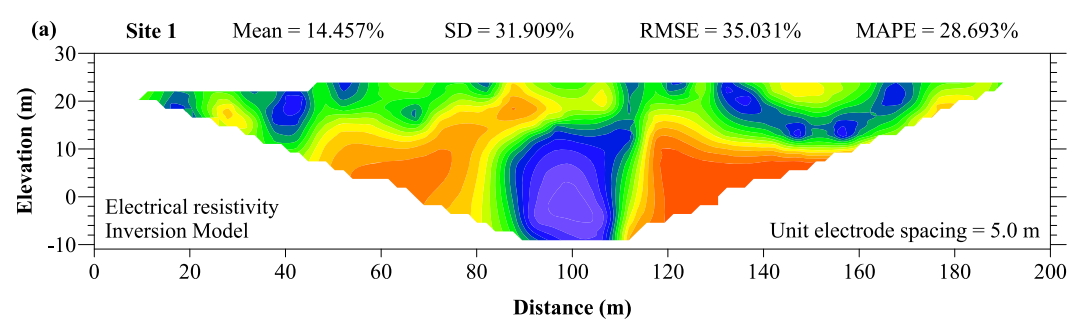

$\%$ Relative Difference (Copper as reference model)

$\begin{array}{llllllll}-70 & -50 & -30 & -10 & 10 & 30 & 50 & 70\end{array}$

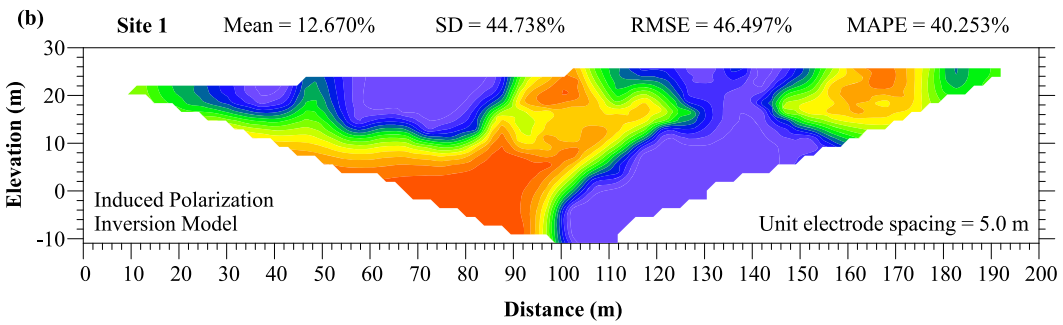

Fig. 8. Models of percentage relative differences between stainless-steel and copper electrodes for inversions results of ERT (a) and IP (b) beneath Site 1.

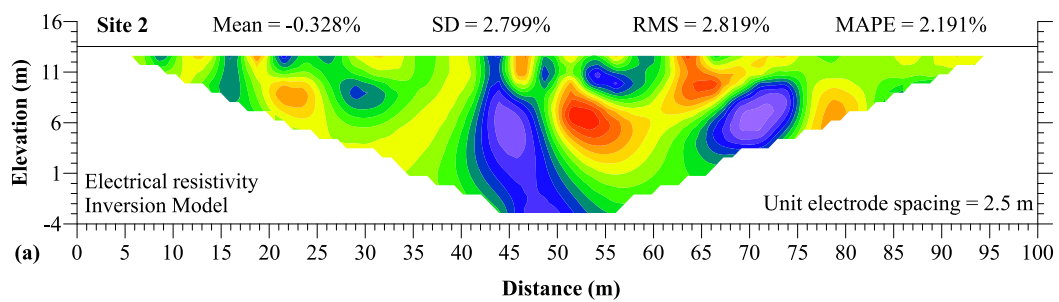

$\%$ Relative Difference (Copper as reference model)
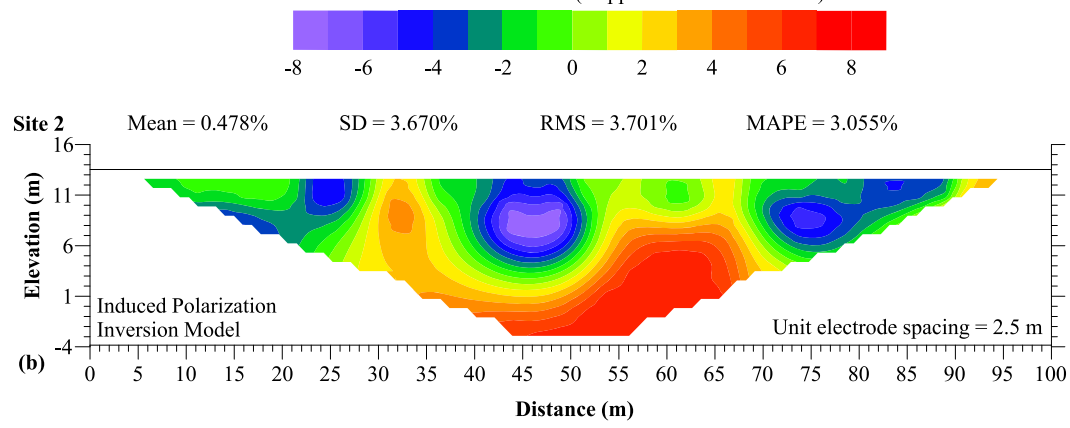

Fig. 9. Models of percentage relative differences between stainless-steel and copper electrodes for inversions results of ERT (a) and IP (b) beneath Site 2. 
their resistivity values were also reduced by water saturation (Griffiths and Barker, 1993; Dahlin et al., 2002; Binley and Kemna, 2005; Binley, 2015; Binley et al., 2015; Amaya et al., 2016; Mashhadi et al., 2020; Rucker et al., 2021). Groundwater in the hard rock aquifers usually occurs either in fractures or in weathered bedrock troughs (Kim et al., 200\%; Arora and Ahmed, 2011; Akingboye et al., 2019; Hasan et al., 2020; Akingboye and Osazuwa, 2021). The subsurface condition of the study area has a high potential for groundwater abstraction despite the limited delineated fractures. Generally, the thicknesses of the topsoil (i.e., sandy silt) and weathered layer (i.e., the composition of the sandy silt, sand, and silty sand) are about $5 \mathrm{~m}$ and $>40 \mathrm{~m}$, respectively, as shown in Figs. 4-7. The silty sand occurs as a thin section of about $1.5 \mathrm{~m}$ in thickness at the depths of about $30-31.5 \mathrm{~m}$ beneath Site 1 (see Figs. 1e and 4).

The highly developed deep-weathered profiles beneath the two sites in the study area support the development of sustainable groundwater. The weathered features were developed by the deep weathering of the feldsparrich granitic bedrock (e.g., Balarabe and Bery, 2021). Such susceptible minerals (i.e., feldspars), including minerals like micas and amphiboles, create appreciably thick weathered strata over a long time due to progressive weathering (Robineau et al., 2007; Bery, 2016; Akingboye and Osazuwa, 2021). The geometries of sections with sand (i.e., A and D) have appreciable thicknesses and widths, particularly in Fig. 6. The inferred fractured and/or deep-weathered zones between stations at $120 \mathrm{~m}$ and $140 \mathrm{~m}$ in Figs. 4-5, and $50 \mathrm{~m}$ and $70 \mathrm{~m}$ in Figs. 6-7 are envisioned as groundwater conduits in the area. Nonetheless, most sections of the subsurface weathered layers are considered aquifers because of the delineated depths of about $>40 \mathrm{~m}$. However, careful delineation of silt-free aquifer zones is highly important to the abstraction of sufficient potable water in the study area. Since the fractured and/or deep-weathered zones contain little or no amount of silt and have resistivity and chargeability values of $<200 \Omega \mathrm{m}$ and $>1.8$ msec, respectively (Figs. $4-7$ ), hence, are suggestive of high potable groundwater-yielding potential. However, since half of the investigated sites are characterised by silt mixed with little or no sand, groundwater yield may be reduced due to groundwater occlusion caused by the relatively low permeability of silty strata, and the possibility of silt precipitation is envisaged as possible pollution. 


\section{Concluding remarks}

The subsurface lithostratigraphic units and groundwater potential of Site 1 and Site 2 within USM, Penang Island, Malaysia, have been evaluated using the resolution capacities of stainless-steel and copper electrodes at dual-spacing, as well as borehole data. The evaluated subsurface resolution capacities of the ERT and IP inversion results at $2.5 \mathrm{~m}$ and $5.0 \mathrm{~m}$ electrode spacing based on field-data and inversion qualities (i.e., the total of data points, RMS errors, percentage of relative differences, and MAPE) suggested higher performances for copper electrodes than the stainless-steel electrodes for Site 1. However, at Site 2, both electrodes tend to perform excellently well based on all the analysed models and statistical parameters.

Generally, the ERT and IP models for the study area obtained through copper electrodes offer a higher resolution contrast for subsurface lithostratigraphic units than the stainless-steel electrodes. The observed variability in resistivity and chargeability values was due to the heterogeneity of the subsurface lithostratigraphic units characterised as sandy silt, sand, and silty sand, and saturating water fills within fractured and/or deep-weathered zones. The depth of the weathered layer constituents, including the deeplyweathered fractured granitic bedrock is about $>40 \mathrm{~m}$. However, the total depths of models beneath Site 2 are limited to about $>16 \mathrm{~m}$ due to the short profile length and the small electrode spacing that was used. Since both sites are located within the same environment, it is believed that the total model median depth for Site 2 should also be to the same extent as Site 1. Hence, the depth of $>40 \mathrm{~m}$ is considerable enough for abstracting high groundwater-yielding capacity in boreholes to sustain a part of the university community. However, since large sections of the investigated areas consist of high silt mixed with little or no sand, groundwater yield may be reduced due to the relatively low permeability of the soil profiles. It is, therefore, important that intended boreholes in this area be designed properly to prevent the possibility of silt precipitation.

Acknowledgements. We appreciate the Editor-in-Chief and the anonymous reviewer for their insightful comments and suggestions in improving the quality of this work.

Data availability. All data generated or analysed during this study are included in this published article. Other supporting analysed data can be made available from the authors upon reasonable request. 
Declaration of competing interest. The authors declare that they have no known competing financial interests or personal relationships that could have appeared to influence the work reported in this paper.

\section{References}

Abdul Hamid F. A. Z., Abu Bakar A. F., Ng T. F., Ghani A. A., Mohamad Zulkifley M. T., 2019: Distribution and contamination assessment of potentially harmful elements (As, $\mathrm{Pb}, \mathrm{Ni}, \mathrm{Cd}$ ) in top soil of Penang Island, Malaysia. Environ. Earth Sci., 78, 21, 616, doi : 10.1007/s12665-019-8626-0.

Abdullah I., Purwanto H. S., 2001: Deformational history of the Eastern Belt, Peninsular Malaysia. Gondwana Res., 4, 4, 556, doi: 10.1016/S1342-937X(05) 70358-0.

Ahmad F., Yahaya A. S., Farooqi M. A., 2006: Characterization and geotechnical properties of Penang residual soils with emphasis on landslides. Am. J. Environ. Sci., 2, 4, 121-128, doi: 10.3844/ajessp.2006.121.128.

Ahmed A. M., Sulaiman W. N., 2001: Evaluation of groundwater and soil pollution in a landfill area using electrical resistivity imaging survey. Environ. Manag., 28, 5, 655-663, doi: 10.1007/s002670010250.

Akingboye A. S., Bery A. A., 2021: Performance evaluation of copper and stainlesssteel electrodes in electrical tomographic imaging. J. Phys. Sci., 32, 3, 13-29, doi: 10.21315/jps2021.32.3.2.

Akingboye A. S., Ogunyele A. C., 2019: Insight into seismic refraction and electrical resistivity tomography techniques in subsurface investigations. Min.-Geol.-Petrol. Eng. Bull. (Rud.-Geol.-Naft. Zb.), 34, 1, 93-111, doi: 10.17794/rgn.2019.1.9.

Akingboye A. S., Osazuwa I. B., 2021: Subsurface geological, hydrogeophysical and engineering characterisation of Etioro-Akoko, southwestern Nigeria, using electrical resistivity tomography. NRIAG J. Astron. Geophys., 9, 1, 43-57, doi: 10.1080/209 09977.2020 .1868659

Akingboye A. S., Osazuwa I. B., Mohammed M. Z., 2019: Electrical resistivity tomography for sustainable groundwater development in a complex geological area. Mater. Geoenviron., 66, 2, 121-128, doi : 10.2478/rmzmag-2019-0004.

Akingboye A. S., Osazuwa I. B., Mohammed M. Z., 2020: Electrical resistivity tomography for geo-engineering investigation of subsurface defects: a case study of EtioroAkoko highway, Ondo State, southwestern Nigeria. Studia Quat., 37, 2, 101-107, doi: $10.24425 / \mathrm{sq} .2020 .133754$.

Akintorinwa O. J., Atitebi M. O., Akinlalu A. A., 2020: Hydrogeophysical and aquifer vulnerability zonation of a typical basement complex terrain: A case study of Odode Idanre southwestern Nigeria. Heliyon, 6, 8, E04549, doi: 10.1016/j.heliyon. 2020. e04549.

Aladejana J. A., Kalin R. M., Sentenac P., Hassan I., 2020: Hydrostratigraphic characterisation of shallow Coastal aquifers of eastern Dahomey basin, s/w Nigeria, using integrated hydrogeophysical approach; implication for saltwater intrusion. Geosciences, 10, 2, 65, doi: 10.3390/geosciences10020065. 
Amaya A. G., Ortiz J., Durán A., Villazon M., 2018: Hydrogeophysical methods and hydrogeological models: basis for groundwater sustainable management in Valle Alto (Bolivia). Sustain. Water Resour. Manag., 5, 3, 1179-1188, doi: 10.1007/s40899 $-018-0293-x$.

Amaya A. G., Dahlin T., Barmen G., Rosberg J.-E., 2016: Electrical resistivity tomography and induced polarization for mapping the subsurface of alluvial fans: a case study in Punata (Bolivia). Geosciences, 6, 4, 51, doi: 10.3390/geosciences6040 051.

Arora T., Ahmed S., 2011: Characterization of recharge through complex vadose zone of a granitic aquifer by time-lapse electrical resistivity tomography. J. Appl. Geophys., 73, 1, 35-44, doi: 10.1016/j.jappgeo.2010.11.003.

Arora T., Boisson A., Ahmed S., 2016: Non-intrusive hydro-geophysical characterization of the unsaturated zone of South India-A case study. J. Afr. Earth Sci., 122, 88-97, doi: 10.1016/j.jafrearsci.2016.04.021.

Balarabe B., Bery A. A., 2021: Modeling of soil shear strength using multiple linear regression (MLR) at Penang, Malaysia. J. Eng. Res., 9, 3A, 40-51, doi: 10.36909/jer.v9 i3A.7675.

Barker R., Moore J., 1998: The application of time lapse electrical tomography in groundwater studies. Lead. Edge, 17, 10, 1454-1458, doi : 10.1190/1.1437878.

Bery A. A., 2016: Slope monitoring study using soil mechanics properties and 4-D electrical resistivity tomography methods. Soil Mech. Found. Eng., 53, 1, 24-29, doi : 10.1007/s11204-016-9359-7.

Bery A. A., Ismail N. E. H., Muztaza N. M., 2019: Soil properties and behaviour studies using join-interpretation of 4-D electrical resistivity tomography and soil mechanics methods in Penang, Malaysia. In: Conference Proceedings, EAGE-GSM 2nd Asia Pacific Meeting on Near Surface Geoscience and Engineering, April 2019, Volume 2019, 1-5, doi: 10.3997/2214-4609.201900402.

Bery A. A., Saad R., 2012: Clayey sand soil's behaviour analysis and imaging subsurface structure via engineering characterizations and integrated geophysical tomography modelling methods. Int. J. Geosci., 3, 1, 93-104, doi: 10.4236/ijg.2012.31011.

Binley A., 2015: Tools and techniques: DC electrical methods. In: Schubert G. (Ed.): Treatise on geophysics, vol. 11, 2nd ed. Elsevier, New York, 233-259, doi : 10.1016/ B978-0-444-53802-4.00192-5.

Binley A., Hubbard S. S., Huisman J. A., Revil A., Robinson D. A., Singha K., Slater L. D., 2015: The emergence of hydrogeophysics for improved understanding of subsurface processes over multiple scales. Water Resour. Res., 51, 6, 3837-3866, doi : 10.1002/2015WR017016.

Binley A., Kemna A., 2005: DC resistivity and induced polarization methods. In: Rubin Y., Hubbard S. S. (Eds.): Hydrogeophysics. Water Science and Technology Library, vol. 50. Springer, Dordrecht, doi: 10.1007/1-4020-3102-5_5.

Cao J., Yang X., Du G., Li H., 2020: Genesis and tectonic setting of the Malaysian Waterfall granites and tin deposit: Constraints from LA-ICP (MC)-MS zircon U$\mathrm{Pb}$ and cassiterite dating and $\mathrm{Sr}-\mathrm{Nd}-\mathrm{Hf}$ isotopes. Ore Geol. Rev., 118, 103336, doi: $10.1016 / j$.oregeorev.2020.103336. 
Cardarelli E., Di Filippo G., 2009: Electrical resistivity and induced polarization tomography in identifying the plume of chlorinated hydrocarbons in sedimentary formation: a case study in Rho (Milan - Italy). Waste Manag. Res., 27, 6, 595-602, doi: $10.1177 / 0734242 X 09102524$.

Chalikakis K., Plagnes V., Guerin R., Valois R., Bosch F. P., 2011: Contribution of geophysical methods to karst-system exploration: an overview. Hydrogeol. J., 19, 6, 1169-1180, doi: 10.1007/s10040-011-0746-x.

Cheng Q., Tao M., Chen X., Binley A., 2019: Evaluation of electrical resistivity tomography (ERT) for mapping the soil-rock interface in karstic environments. Environ. Earth Sci., 78, 15, 439, doi: 10.1007/s12665-019-8440-8.

Clark A. F., Childs G. E., Wallace G. H., 1970: Electrical resistivity of some engineering alloys at low temperatures. Cryogenics, 10, 4, 295-305, doi: 10.1016/0011-2275 (70) $90056-1$.

Coscia I., Linde N., Greenhalgh S., Vogt T., Green A., 2012: Estimating traveltimes and groundwater flow patterns using 3D time-lapse crosshole ERT imaging of electrical resistivity fluctuations induced by infiltrating river water. Geophysics, 77, 4, E239E250, doi: 10.1190/geo2011-0328.1.

Cosgrove W. J., Loucks D. P., 2015: Water management: current and future challenges and research directions. Water Resour. Res., 51, 6, 4823-4839, doi: 10.1002/2014 WR016869.

Crook N., Binley A., Knight R., Robinson D. A., Zarnetske J., Haggerty R., 2008: Electrical resistivity imaging of the architecture of substream sediments. Water Resour. Res., 44, 4, W00D13, doi: 10.1029/2008WR006968.

Dahlin T., Leroux V., Nissen J., 2002: Measuring techniques in induced polarisation imaging. J. Appl. Geophys., 50, 3, 279-298, doi: 10.1016/S0926-9851(02) 00148-9.

Dahlin T., Loke M. H., 2018: Underwater ERT surveying in water with resistivity layering with example of application to site investigation for a rock tunnel in central Stockholm. Near Surf. Geophys., 16, 3, 230-237, doi : 10.3997/1873-0604.2018007.

Daily W., Ramirez A., Binley A., LaBrecque D., 2005: Electrical resistance tomography: theory and practice. In: Butler D. K. (Ed.): Near-Surface Geophysics (13th ed.), 525-550, (Investigation in geophysics). Society of Exploration Geophysicists, doi: $10.1190 / 1.9781560801719 . \operatorname{ch} 17$.

Daily W., Ramirez A., LaBrecque D., Nitao J., 1991: Electrical resistivity tomography of vadose water movement. Water Resour. Res., 28, 5, 1429-1442, doi : 10.1029/91WR0 3087.

deGroot-Hedlin C., Constable S., 1990: Occam's inversion to generate smooth twodimensional models from magnetotelluric data. Geophysics, 55, 12, 1613-1624, doi: $10.1190 / 1.1442813$.

Ganerød G. V., Rønning J. S., Dalsegg E., Elvebakk H., Holmøy K., Nilsen B., Braathen A., 2006: Comparison of geophysical methods for sub-surface mapping of faults and fracture zones in a section of the Viggja road tunnel, Norway. Bull. Eng. Geol. Environ., 65, 3, 231-243, doi : 10.1007/s10064-006-0041-6. 
Gao Q., Shang Y., Hasan M., Jin W., Yang P., 2018: Evaluation of a weathered rock aquifer using ERT method in South Guangdong, China. Water, 10, 3, 293, doi: 10. 3390/w10030293.

Gourdol L., Clément R., Juilleret J., Pfister L., Hissler C., 2018: Large-scale ERT surveys for investigating shallow regolith properties and architecture. Hydrol. Earth Sys. Sci. Discuss., 39 p., doi : 10.5194/hess-2018-519.

Griffiths D. H., Barker R. D., 1993: Two-dimensional resistivity imaging and modelling in areas of complex geology. J. Appl. Geophys., 29, 3-4, 211-226, doi: 10.1016/0926 -9851 (93) 90005-J.

Hasan M., Shang Y., Akhter G., Jin W., 2020: Delineation of contaminated aquifers using integrated geophysical methods in Northeast Punjab, Pakistan. Environ. Monit. Assess., 192, 1, 12, doi : 10.1007/s10661-019-7941-y.

Hasan M., Shang Y., Akhter G., Khan M., 2017: Geophysical investigation of fresh-saline water interface: a case study from South Punjab, Pakistan. Groundwater, 55, 6, 841-856, doi: 10.1111/gwat.12527.

Hasan M., Shang Y., Jin W., Akhter G., 2019: Assessment of aquifer vulnerability using integrated geophysical approach in weathered terrains of South China. Open Geosci., 11, 1, 1129-1150, doi : 10.1515/geo-2019-0087.

Hayley K., Bentley L. R., Gharibi M., 2009: Time-lapse electrical resistivity monitoring of salt-affected soil and groundwater. Water Resour. Res., 45, 7, W07425, doi: $10.1029 / 2008$ wr007616.

Hojat A., Arosio D., Ivanov V. I., Loke M. H., Longoni L., Papini M., Tresoldi G., Zanzi L., 2020: Quantifying seasonal 3D effects for a permanent electrical resistivity tomography monitoring system along the embankment of an irrigation canal. Near Surf. Geophys., 18, 4, 427-443, doi : 10.1002/nsg.12110.

Karim M. Z., Tucker-Kulesza S. E., 2017: Two-dimensional soil erosion profile using electrical resistivity surveys. In: Brandon T. L., Valentine R. J. (Eds.): Geotechnical Frontiers 2017: Foundations. ASCE, Reston, VA, 50-58, doi: 10.1061/978078448 0465.006.

Karim M. Z., Tucker-Kulesza S. E., 2018: Predicting soil erodibility using electrical resistivity tomography. J. Geotech. Geoenviron. Eng., 144, 4, 04018012, doi: 10.1061/ (ASCE) GT . 1943-5606.0001857.

Kim J.-H., Yi M.-J., Hwang S.-H., Song Y., Cho S.-J., Synn J.-H., 2007: Integrated geophysical surveys for the safety evaluation of a ground subsidence zone in a small city. J. Geophys. Eng., 4, 3, 332-347, doi: 10.1088/1742-2132/4/3/S12.

LaBrecque D., Daily W., 2008: Assessment of measurement errors for galvanic-resistivity electrodes of different composition. Geophysics, 73, 2, F55-F64, doi : 10.1190/1.28 23457.

Loke M. H., 2004: Rapid 2-D resistivity and IP inversion using the least-square method. Manual for RES2DINV (ver. 3.54), Geotomo Software, 53 p.

Loke M. H., Chambers J. E., Rucker D. F., Kuras O., Wilkinson P. B., 2013: Recent developments in the direct-current geoelectrical imaging method. J. Appl. Geophys., 95, 135-156, doi: 10.1016/j.jappgeo.2013.02.017. 
Maiti S., Erram V. C., Gupta G., Tiwari R. K., 2012: ANN based inversion of DC resistivity data for groundwater exploration in hard rock terrain of western Maharashtra (India). J. Hydrol., 464-465, 294-308, doi : 10.1016/j . jhydrol.2012.07.020.

Martínez J., Rey J., Sandoval S., Hidalgo M. C., Mendoza R., 2019: Geophysical prospecting using ERT and IP techniques to locate Galena veins. Remote Sens., 11, 24, 2923, 14 p., doi: $10.3390 /$ rs11242923.

Mashhadi S. R., Nikfarjam M., Mehrnia A. K., 2020: Reinterpretation of resistivity and induced polarization data to explore gold mineralization zones at Zarzima prospect, Iran. Acta Geol. Slovaca, 12, 1, 15-22.

McLachlan P., Chambers L., Uhlemann S., Sorensen J., Binley A., 2020: Electrical resistivity monitoring of river-groundwater interactions in a Chalk river and neighbouring riparian zone. Near Surf. Geophys., 18, 4, 385-398, doi: 10.1002/nsg. 12114.

Metcalfe I., 2000: The Bentong-Raub Suture Zone. J. Asian Earth Sci., 18, 6, 691-712, doi: 10.1016/S1367-9120(00)00043-2.

Metcalfe I., 2001: The Bentong-Raub Suture zone, Permo-Triassic orogenesis and amalgamation of the Sibumasu and Indochina Terranes. Gondwana Res., 4, 4, 700-701, doi : 10.1016/S1342-937X (05) 70498-6.

Metcalfe I., 2013: Tectonic evolution of the Malay Peninsula. J. Asian Earth Sci., 76, 195-213, doi: 10.1016/j.jseaes.2012.12.011.

Muchingami I., Hlatywayo D. J., Nel J. M., Chuma C., 2012: Electrical resistivity survey for groundwater investigations and shallow subsurface evaluation of the basalticgreenstone formation of the urban Bulawayo aquifer. Phys. Chem. Earth, 50-52, 44-51, doi: 10.1016/j.pce.2012.08.014.

Ng S. W.-P., Chung S.-L., Robb L. J., Searle M. P., Ghani A. A., Whitehouse M. J., Oliver G. J. H., Sone M., Gardiner N. J., Roselee M. H., 2015a: Petrogenesis of Malaysian granitoids in the Southeast Asian tin belt: Part 1. Geochemical and Sr-Nd isotopic characteristics. Geol. Soc. Am. Bull., 127, 9-10, 1209-1237, doi: $10.1130 /$ B31213.1.

Ng S. W.-P., Whitehouse M. J., Searle M. P., Robb L. J., Ghani A. A., Chung S.-L., Oliver G. J. H., Sone M., Gardiner N. J., Roselee M. H., 2015b: Petrogenesis of Malaysian granitoids in the Southeast Asian tin belt: Part 2. U-Pb zircon geochronology and tectonic model. Geol. Soc. Am. Bull., 127, 9-10, 1238-1258, doi: 10. 1130/B31214.1.

Ong W. S., 1993: The geology and engineering geology of Pulau Pinang. Geological Survey of Malaysia, Map report, 7, $74 \mathrm{p}$.

Raji W. O., Abdulkadir K. A., 2020: Evaluation of groundwater potential of bedrock aquifers in Geological Sheet 223 Ilorin, Nigeria, using geo-electric sounding. Appl. Water Sci., 10, 220, doi: 10.1007/s13201-020-01303-2.

Rakoto H. A., Rajaomahefasoa R., Razafiarisera R., Razafindrakoto B., 2019: Evaluation of flake graphite ore using self-potential (SP), electrical resistivity tomography (ERT) and induced polarization (IP) methods in east coast of Madagascar. J. Appl. Geophys., 169, 134-141, doi : 10.1016/j.jappgeo.2019.07.001. 
Robineau B., Join J. L., Beauvais A., Parisot J.-C., Savin C., 2007: Geoelectrical imaging of a thick regolith developed on ultramafic rocks: groundwater influence. Aust. J. Earth Sci., 54, 5, 773-781, doi : 10.1080/08120090701305277.

Rucker D. F., Tsai C.-H., Carroll K. C., Brooks S., Pierce E. M., Ulery A., Derolph C., 2021: Bedrock architecture, soil texture, and hyporheic zone characterization combining electrical resistivity and induced polarization imaging. J. Appl. Geophys., 188, 104306, doi: 10.1016/j.jappgeo.2021.104306.

Sağır Ç., Kurtuluş B., Soupios P., AyrancıK., Düztaş E., Aksoy M. E., Avşar Ö., Erdem G., Pekkan E., Canoğlu M. C., Kaka S. I., Razack M., 2020: Investigating the structure of a coastal karstic aquifer through the hydrogeological characterization of springs using geophysical methods and field investigation, Gökova Bay, SW Turkey. Water, 12, 12, 3343, doi: 10.3390/w12123343.

Schwartz M. O., Rajah S. S., Askury A. K., Putthapiban P., Djaswadi S., 1995: The Southeast Asian Tin Belt. Earth-Sci. Rev., 38, 95-293, doi : 10.1016/0012-8252 (95) 00004-T.

Silvester P. P., Ferrari R. L., 1996: Finite elements for electrical engineers (3rd ed.). Cambridge University Press, 514 p., doi : 10.1017/CB09781139170611.

Sirhan A., Hamidi M., Andrieux P., 2011: Electrical resistivity tomography, an assessment tool for water resource: a case study of Al-Aroub Basin, West Bank, Palestine. Asian J. Earth Sci., 4, 1, 38-45, doi: 10.3923/ajes.2011.38.45.

Slater L. D., Glaser D. R., 2003: Controls on induced polarization in sandy unconsolidated sediments and application to aquifer characterization. Geophysics, 68, 5, 1547-1558, doi: $10.1190 / 1.1620628$.

Slater L. D., Lesmes D., 2002: IP interpretation in environmental investigations. Geophysics, 67, 1, 77-88, doi : 10.1190/1.1451353.

Soupios P. M., Kouli M., Vallianatos F., Vafidis A., Stavroulakis G., 2007: Estimation of aquifer hydraulic parameters from surficial geophysical methods: a case study of Keritis Basin in Chania (Crete - Greece). J. Hydrol., 338, 1-2, 122-131, doi: $10.1016 / j \cdot j h y d r o l .2007 .02 .028$.

Storz H., Storz W., Jacobs F., 2000: Electrical resistivity tomography to investigate geological structures of the Earth's upper crust. Geophys. Prospect., 48, 3, 455471, doi : $10.1046 / \mathrm{j} .1365-2478.2000 .00196 . x$.

Tremsin V. A., 2017: Real-time three-dimensional imaging of soil resistivity for assessment of moisture distribution for intelligent irrigation. Hydrology, 4, 4, 54, doi: $10.3390 /$ hydrology 4040054 .

Uhlemann S., Kuras O., Richards L. A., Naden E., Polya D. A., 2017: Electrical resistivity tomography determines the spatial distribution of clay layer thickness and aquifer vulnerability, Kandal Province, Cambodia. J. Asian Earth Sci., 147, 402414, doi: $10.1016 / j \cdot j$ seaes . 2017.07.043. 


\section{Appendix}

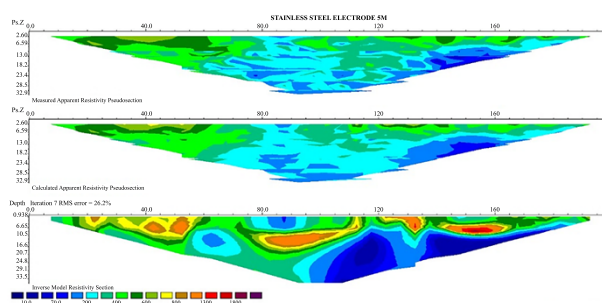

(a)

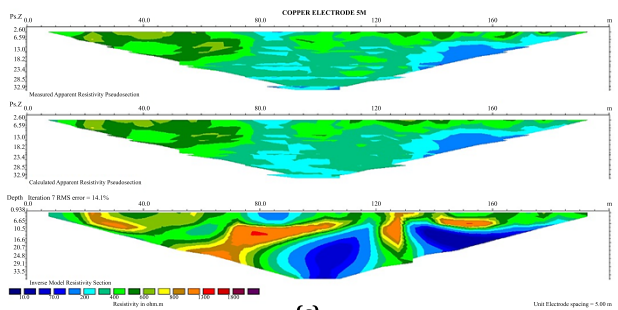

(c)

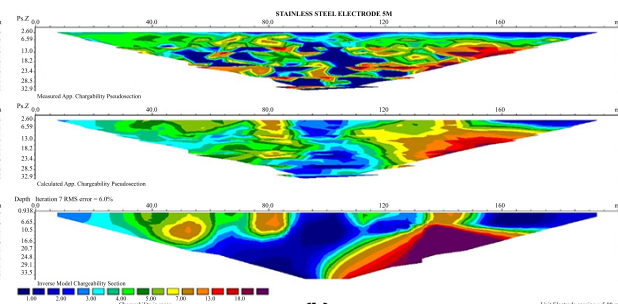

(b)
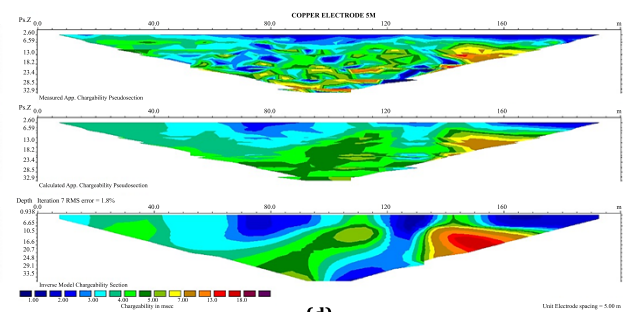

(d)

Appendix 1. Composite plots of pseudosections of the results of 2D ERT and IP inversions beneath traverse Site 1 for the stainless-steel electrodes ( $a, b)$ and the copper electrodes (c, d) at electrode spacing of $5 \mathrm{~m}$.

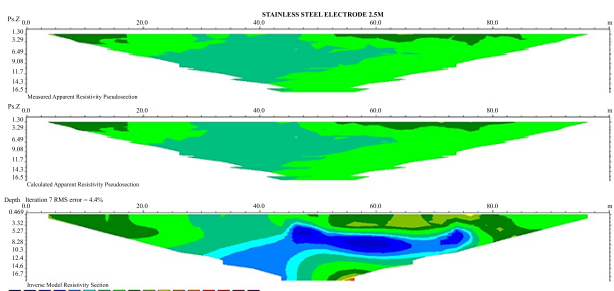

(a)

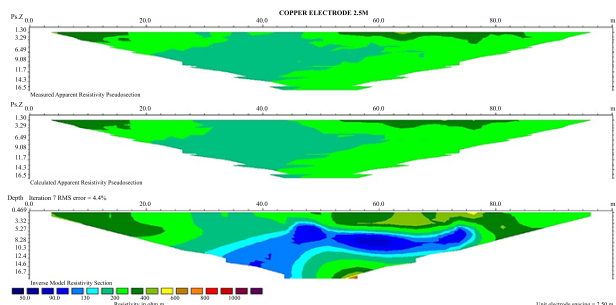

(c)

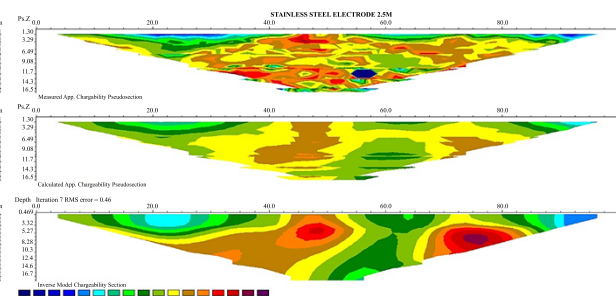

(b)

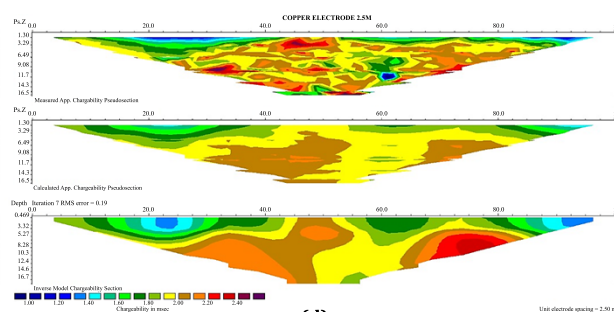

(d)

Appendix 2. Composite plots of pseudosections of the results of 2D ERT and IP inversions beneath traverse Site 2 for the stainless-steel electrodes $(a, b)$ and the copper electrodes (c, d) at electrode spacing of $2.5 \mathrm{~m}$. 